Témoigner Témoigner. Entre histoire et mémoire

Getuigen Revue pluridisciplinaire de la Fondation Auschwitz

$121 \mid 2015$

Violences radicales en scène

\title{
Zef Bunga heeft Anne Frank gekust
}

Representatie van geweld in het Nederlands jeugdtheater

Zef Bunga a embrassé Anne Frank. Représentation de la violence dans le théâtre

jeunesse néerlandais

\section{Cock Dieleman et Veronika Zangl}

\section{Q OpenEdition \\ Journals}

\section{Édition électronique}

URL : https://journals.openedition.org/temoigner/3363

DOI : 10.4000/temoigner.3363

ISSN : 2506-6390

Éditeur :

Éditions du Centre d'études et de documentation Mémoire d'Auschwitz, Éditions Kimé

Édition imprimée

Date de publication : 1 octobre 2015

Pagination : 64-74

ISSN : 2031-4183

Référence électronique

Cock Dieleman en Veronika Zangl, «Zef Bunga heeft Anne Frank gekust», Témoigner. Entre histoire et mémoire [Online], 121 | 2015, Online op 01 octobre 2016, geraadpleegd op 03 février 2022. URL: http:// journals.openedition.org/temoigner/3363 ; DOI: https://doi.org/10.4000/temoigner.3363 


\section{Zef Bunga heeft \\ Anne Frank gekust}

Representatie van geweld in het Nederlands jeugdtheater

$\rightarrow$ Cock Dieleman

\& Veronika Zangl,

Universiteit van Amsterdam

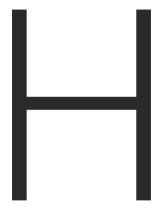

et dagboek van Anne Frank werd al snel na publicatie een symbool voor de gruweldaden van het Nationaalsocialisme. Met de dramatisering en verfilming van haar dagboek in de jaren 1950 werd Anne Frank tot ultieme herinneringsfiguur van de Holocaust en tot icoon van een universeel begrip van humanisme. Het debat rond het 'fenomeen Anne Frank' (Barnouw 2012) wordt gekenmerkt door een verschijnsel dat door Marvin Carlson als ghosting wordt omschreven. Van ghosting is volgens Carlson sprake wanneer de toeschouwers van een theatervoorstelling geconfronteerd worden met 'the identical thing they have encountered before, although now in a somewhat different context (Carlson 2003, 7). Ghosting doet zich volgens Carlson in alle kunstvormen voor, maar vooral het theater is in belangrijke mate 'obsessed with memory and ghosting' (7).

In het discours rond Anne Frank en haar dagboek keren twee tegenstrijdige interpretaties telkens terug (Bachmann 2010, 137-185): Anne Frank als universeel boegbeeld van humanisme en Anne Frank als icoon voor de vernietiging van Joden tijdens de Holocaust. Zoals al bij de eerste vermelding van het dagboek in de voormalige verzetskrant Het Parool duidelijk wordt, gaat het debat om het afbakenen van wat wel en niet tot het leed van de Holocaust gerekend kan of mag worden. Jan Romein beklemtoont in zijn bijdrage op de voorpagina onder de titel 'Kinderstem':

\footnotetext{
Voor mij echter is in dit schijnbaar onbetekenende dagboek van een kind, in dit door een kinderstem gestamelde 'de profundis' alle afzichtelijkheid van het fascisme belichaamd, méér dan in alle processtukken van Neurenberg bij elkaar. Voor mij is in het lot van dit joodse meisje de ergste misdaad samengevat die de eeuwigverfoeilijke geest beging. Want die ergste misdaad is niet de vernietiging van leven en cultuur op zichzelf - deze kunnen ook aan een cultuurscheppende revolutie ten offer vallen - maar het verstoppen van de bronnen der cultuur, de vernietiging van leven en talent alleen uit domme vernietigingsdrift. (Romein 1946, 1)
}

Een jaar later zal het dagboek onder de titel Het achterhuis verschijnen. Een wereldwijd succes wordt het echter pas na de publicatie van de Amerikaanse vertaling The Diary of Anne Frank en de recensie van Meyer Levin die wederom een 


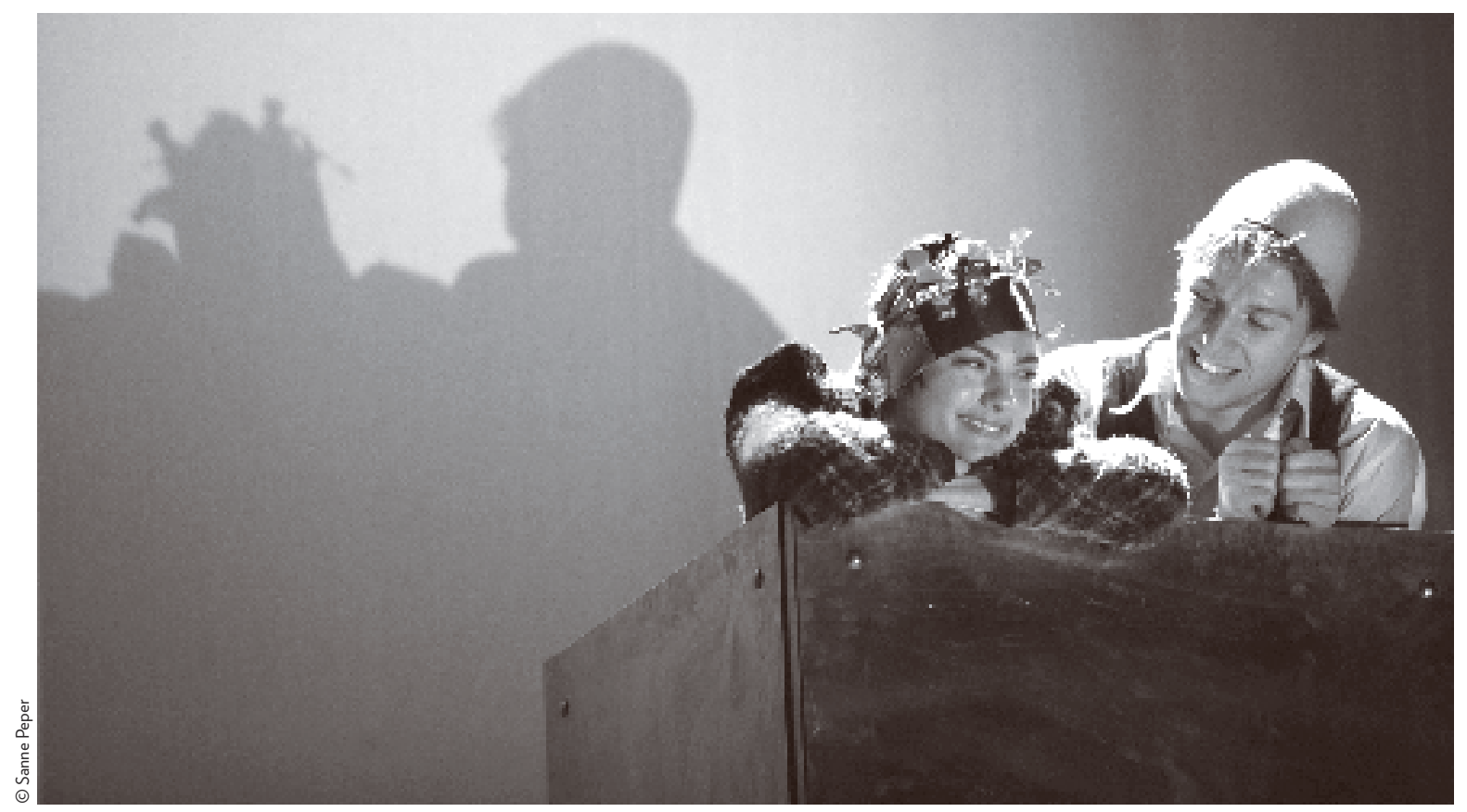

titelpagina haalt, dit keer van de gerenommeerde New York Times Book Review. In _ Laura de Boer en Floris Verkerk in Anne en Zef, de Toneelmakerij, 2009. tegenstelling tot Romein ziet Levin Anne Frank niet als het symbool van de fascistische 'vernietiging van leven en talent' in het algemeen, maar als levende stem van de vernietiging van de Joden:

Because the diary was not written in retrospect, it contains the trembling life of every moment - Anne Frank's voice becomes the voice of six million vanished Jewish souls. (Levin 1952, 1)

In de volgende decennia richt de kritiek op de iconische status van Anne Frank en haar dagboek zich op twee aspecten: ten eerste de overlapping van onderduiken en vernietiging, waardoor de Holocaust als het ware uit het zicht verdwijnt; ten tweede de ontkenning van het feit dat Anne Frank een Joods meisje was en daarom moest onderduiken en vermoord werd. In zijn herinneringen Moeder was niet thuis voor haar begrafenis constateert Menachem Samuel Arnoni bijvoorbeeld:

Waar ik tegen in opstand kwam was dat dit boek als kenmerkend voor de jodenvervolging werd gezien en daardoor populair werd. Dat is het helemaal niet. De belevenissen van Anne Frank zoals die in haar dagboek zijn opgetekend zijn eerder niet-kenmerkend dan kenmerkend. [...] De overgrote meerderheid, de miljoenen in getto's, werkkampen, vernietigingskampen [...] hebben een lot ondergaan dat zo wezenlijk veel droeviger was dan dat opgetekend door het jonge Amsterdamse meisje, dat ze niet gesymboliseerd kunnen worden door wat zij had te zeggen. (Arnoni 1982, 283) 
Zef Bunga heeft

Anne Frank gekust

(vervolg)
(1) In de publiciteitsuitingen van Theater Amsterdam wordt Anne vooral als getalenteerd schrijfster geportretteerd: 'Wie was Anne Frank? Haar dagboek werd de beroemde nalatenschap van een verdwenen Joods meisje. Ook wie het niet gelezen heeft, denkt het verhaal van Anne Frank te kennen, maar pas in de laatste jaren is het langzaam tot ons door gedrongen dat Anne behalve een levend, sterk en sprankelend pubermeisje, een echte schrijfster was.' http://www. theateramsterdam.nl/nl/Annede-theatervoorstelling/synopsis. html
Arnoni's commentaar kan als echo gelezen worden van Bruno Bettelheims kritiek op de Broadwayproductie van The Diary of Anne Frank (1955), die het schrijversechtpaar Frances Goodrich en Albert Hackett met de volgende zin laat eindigen: 'In spite of everything, I still believe that people are really good at heart.' (Goodrich \& Hackett 1964, 87) Bettelheim concludeert in zijn kritiek dat dat einde de belangrijkste reden is voor het succes van de voorstelling, maar ' what is evaded is the importance of accepting the gas chambers as real so that never again will they be allowed to exist' (Bettelheim 1960,46). Soortgelijke argumentatie is terug te vinden in de studies van Alvin Rosenfeld (1980, 51), Lawrence Langer (1996, 158) of James E. Young (1988, 27-28) die het literatuur- en cultuurwetenschappelijke discours over de Holocaust in de jaren tachtig en negentig mee hebben bepaald.

De discussie hoe Joods Anne Frank wel of niet gerepresenteerd moet worden begint feitelijk met de toneeladaptie van het dagboek die Otto Frank oorspronkelijk Meyer Levin had toegezegd. Uiteindelijk werd het door het niet-Joodse echtpaar Goodrich en Hackett voor toneel bewerkt. Ensceneringen van het dagboek vanaf de jaren tachtig beklemtonen juist de Joodse identiteit van actrices en bewerkers. De verschillende manieren van toe-eigening vat Cynthia Ozick in haar artikel Who owns Anne Frank als volgt samen:

But the diary in itself richly crammed though it is with incident and passion, cannot count as Anne Frank's story. A story may not be said to be a story if the end is missing. And because the end is missing, the story of Anne Frank in the fifty years since The Diary of a Young Girl was first published has been bowdlerized, distorted, transmuted, traduced, reduced; it has been infantilized, Americanized, homogenized, sentimentalized; falsified, kitschified, and, in fact, blatantly and arrogantly denied. (Ozick 2000, 77)

Bovenstaand citaat geeft duidelijk weer hoe het fenomeen 'ghosting' in het theater, maar ook in andere vormen van kunst en literatuur kan werken. Ook de producenten van Anne, de meest recente bewerking van het dagboek, die in mei 2014 in Amsterdam in première ging, gaan ghosting niet uit de weg. Met Jessica Durlacher en Leon de Winter wordt namelijk wederom aan een schrijversechtpaar de opdracht voor de bewerking en toegang tot de verschillende versies van het dagboek gegeven, maar in dit geval een echtpaar met een expliciet Joodse achtergrond en een oeuvre dat regelmatig de gevolgen van de Holocaust als onderwerp heeft. De vader van Jessica Durlacher, Gerhard Durlacher, heeft Westerbork, Theresienstadt en Auschwitz overleefd, wat haar bovendien tot tweede generatie overlevende maakt.

Kenmerkend voor de bewerking van het dagboek door Durlacher en De Winter is de dubbele raamvertelling. In het begin van de voorstelling horen we de stem van Anne die in het kamp aan haar zus Margot een droombeeld beschrijft, waarin zij na de oorlog in een Parijs' café belandt. In dat café vertelt ze haar dagboek aan een uitgever. ${ }^{1}$ De rest van de voorstelling is vooral een getrouwe weergave van de gebeurtenissen die in het dagboek worden beschreven, al wordt helemaal aan het eind ook het concentratiekamp verbeeld om de buitenste raamvertelling af te ron- 
den. De vormgeving, gedomineerd door halfronde bewegende projectieschermen, brengt alle locaties hyperrealistisch in beeld: het Parijse café, het ouderlijk huis van Anne in Amsterdam, het achterhuis, en ten slotte de barre omgeving van het concentratiekamp in Bergen-Belsen. De (draai)decors van Bernhard Hammer suggereren authenticiteit, maar veel recensenten merken op 'dat de enorme schaal waarop deze productie wenst te werken, misschien niet past bij het claustrofobische huiskamerdrama dat het verhaal van het Achterhuis uiteindelijk toch is' (Van den Berg 2014).

Spektakel en schaalvergroting kenmerken ook de marketing rondom de voorstelling. Voor Anne wordt een geheel nieuw Amsterdams theater gebouwd en een theaterbezoek wordt voor de zakelijke markt gekoppeld aan een boottochtje voorafgaand aan de voorstelling, en een dinerarrangement met champagne. Het discours rondom de productie spitst zich uiteindelijk toe op de vraag of de feestelijke champagne gepast is bij een voorstelling die de Jodenvervolging tot onderwerp heeft. Ook hier is sprake van ghosting. In een brief aan Levin schreef Otto Frank al zijn bedenkingen over de dramatisering van het dagboek. Hij was bang dat een regisseur het noodzakelijk zou vinden vooral de opwinding en spanning van het onderduiken te benadrukken om het publiek te entertainen (vgl. Bachmann 2010, 159). Ondanks de grote schaal van de productie en de imponerende decors wordt de voorstelling Anne lauw ontvangen. 'Anne is een imponerende, maar brave en eendimensionale voorstelling', schrijft Herien Wensink in haar recensie (Wensink 2014, 1). De NRC, Nederlands kwaliteitskrant bij uitstek, plaatste haar kritiek prominent op de voorpagina, wat van zichzelf dan weer een nationaal nieuwsitem werd. ${ }^{2}$

In tegenstelling tot Anne is de kleinschalige jeugdvoorstelling Anne en Zef, die in 2009 in première ging en sindsdien meerdere malen is hernomen, ${ }^{3}$ niet op zoek naar de 'werkelijke Anne' achter het icoon maar focust op het traumatiserende geweld dat kinderen ondergaan. De voorstelling is geproduceerd door de Toneelmakerij, een van Nederlands belangrijkste jeugdtheatergezelschappen. De voorstelling breekt op minstens drie manieren met taboes rondom de getuigenis en representatie van de Holocaust. In de eerste plaats omdat de Holocaust niet als unieke gebeurtenis wordt uitgebeeld maar samen met andere vormen van geweld in kaart wordt gebracht. In de tweede plaats omdat het verhaal van Anne Frank een fictieve voortzetting van haar dagboek is. In die zin gaat schrijver en regisseur De Bont lijnrecht in tegen het idee dat representaties van de Holocaust altijd accuraat en getrouw aan de historische feiten moeten zijn (Des Pres 1988, 217). En in de derde plaats omdat al deze gruwelijkheden juist in een voorstelling voor kinderen aan bod komen, waarbij de scherpe en soms humorvolle dialogen het confronterende thema voor hen toch draaglijk maken.

\section{REPRESENTATIE VAN GEWELD IN HET NEDERLANDS JEUGDTHEATER}

Het Nederlandse jeugdtheater heeft internationaal al een kwarteeuw een vooraanstaande positie (Van de Water 2012, 30). Het kwam in de jaren zeventig van de vorige eeuw tot bloei, toen vooral de groepen binnen het politieke vormingstoneel de jeugd als publiek uitkozen. Hun doel was om de kinderen en jongeren zich van
(2) Vermoedelijk onbedoeld sluit ook de redactie van de NRC zich aldus aan bij de 'traditie' van Anne Frank als voorpaginanieuws, zoals hierboven beschreven.

(3) Inmiddels is het toneelstuk bovendien als opera bewerkt; op 18 april 2015 ging de jeugdopera Anne en Zef in Muziekgebouw aan ' $\mathrm{I} \mathrm{J}$ te Amsterdam in première (libretto Ad de Bont; componist Monique Krüs; regie Corina van Eijk) 
Zef Bunga heeft

Anne Frank gekust

(vervolg)

(4) Deze thema's zijn ruimschoots aanwezig in sprookjes - het literaire, dramatische en filmische genre voor kinderen par excellence -, maar sprookjes werden vanaf de jaren zeventig juist op grond van het alomtegenwoordige geweld vanuit pedagogisch, sociaalwetenschappelijk en feministisch perspectief bekritiseerd, als repressief gedevalueerd en uiteindelijk zonder geweld op een zogenaamd kindvriendelijke manier geherformuleerd. Het is opmerkelijk dat Bruno Bettelheim, onder andere vanuit zijn ervaring in concentratiekampen, het belang van sprookjes voor kinderen verdedigt (vgl. Bettelheim 1980). hun positie in de samenleving bewust te maken en hen tegen de gevestigde orde in het geweer te laten komen (Van Maanen 1997, 160). In de jaren tachtig verloor dat vormingstoneel echter aan belang en gingen de jeugdtheatermakers zich meer richten op de belevingswereld van het kind zelf. Daarbij werden zowel complexe en controversiële onderwerpen als radicale artistieke keuzes niet geschuwd.

Vanaf de jaren negentig van de vorige eeuw zijn het niet alleen de makers die naam maken, maar komt tevens een aantal schrijvers voor het jeugdtheater in de belangstelling te staan, ook internationaal. Zij nemen met hun stukken enerzijds de wereld van het kind serieus, maar gaan anderzijds 'volwassen' onderwerpen als seks, geweld en dood niet uit de weg. ${ }^{4}$ In die tijd worden twee benaderingen om geweld in het jeugdtheater te reflecteren zichtbaar. Ten eerste worden klassieke tragedies voor kinderen bewerkt; ten tweede worden actuele en recente historische gebeurtenissen gedramatiseerd.

Pauline Mol bewerkte vanaf 1989 een aantal Griekse tragedies van Euripides en stond daarmee aan de wieg van een traditie in het Nederlands jeugdtheater, waarin klassieke teksten zo worden bewerkt, dat de kinderen de hoofdpersonen worden. In Mols tragediebewerkingen zijn die kinderen niet alleen de belangrijkste personages, maar ook de slachtoffers van geweld en van beslissingen die door volwassenen genomen worden. In Euripides' Ifigeneia in Aulis bijvoorbeeld is Agamemnon de protagonist. Hij moet zijn dochter Ifigeneia offeren aan de godin Artemis om de wind te laten draaien, opdat de Griekse schepen naar Troje kunnen varen. In Ifigeneia Koningskind (1989) van $\mathrm{Mol}$ is dat perspectief verschoven naar Ifigeneia zelf, geflankeerd door het personage Kind. De toeschouwers beleven de tragische gebeurtenissen door hun ogen (Meyer 1996, 832-34).

Met de dramatisering van recente of actuele geschiedenis voor het jeugdtheater trok in 1993 een andere schrijver en regisseur de aandacht. Ad de Bont schreef Mirad een jongen uit Bosnië naar aanleiding van het toen actuele oorlogsgeweld in Bosnië-Herzegovina voor zijn eigen groep Wederzijds. Onderwerp van het stuk is dus niet meer de actualisering van een mythe uit een andere tijd en een andere cultuur maar een actuele oorlog in het centrum van Europa. Mirad is een dertienjarige Bosnische jongen, die als gevolg van de oorlog vrijwel al zijn dierbaren heeft verloren. Na de verdwijning van zijn moeder en de dood van zijn vader en zusje belandt hij als vluchteling in Nederland.

Omdat Wederzijds vrijwel uitsluitend schoolvoorstellingen speelde, was het stuk zo gestructureerd dat het met minimale middelen in klaslokalen kon worden opgevoerd. Twee acteurs, die de oom en tante van Mirad spelen, vertellen als vluchtelingen in Nederland het verhaal van Mirad, deels aan de hand van dagboekaantekeningen en een brief van de hoofdpersoon:

Toen we in Nederland aankwamen belden we meteen naar het pleeggezin waarbij Mirad sinds een paar maanden woonde. Toen hoorden we dat hij diezelfde nacht spoorloos was verdwenen. Hij had zijn dagboek voor ons achtergelaten en op de laatste bladzijde stond deze brief. (De Bont 1993, 36) 
Uit de brief blijkt dat Mirad is teruggegaan naar Bosnië om zijn moeder te zoeken. ${ }^{5} \mathrm{Als}$ herinneringskader om het verhaal van Mirad te vertellen kiest de Bont dus geen motief van een klassieke tragedie maar de spookachtige gelijktijdigheid van aanwezigheid en afwezigheid die ook Anne Franks dagboek kenmerkt. Net als bij Anne Frank staat het dagboek symbool voor de breuk tussen het verleden en het heden. Echter, in tegenstelling tot de dramatisering van het dagboek van Anne Frank blijft niet alleen Mirad als personage, maar ook zijn stem afwezig. De getuige van de oorlog in Bosnië, de titelheld Mirad, wordt in De Bonts stuk als het ware als verlies geënsceneerd. Het is de afwezigheid die in het bijzonder wordt benadrukt: afwezigheid van identiteit, van familiebanden, van andere verbintenissen, en in een bredere zin afwezigheid van tijdsverloop, d.w.z. de mogelijkheid de beleefde gebeurtenissen tot ervaring en geschiedenis te transformeren. Zijn verhaal kunnen enkel zijn oom en zijn tante lezen en vertalen.

De impact van tekst en voorstelling was enorm. Het stuk werd vertaald in veertien talen en overal over de wereld gespeeld. Hoewel De Bont toen al een decennium lang artistiek leider was van Wederzijds, werd met Mirad een jongen uit Bosnië zijn naam als toneelschrijver definitief gevestigd. De Bont schreef een groot aantal toneelstukken voor kinderen en geldt als de belangrijkste Nederlandse toneelschrijver voor de jeugd. Toch was die waardering niet altijd onomstreden. In 2007 schreef en regisseerde De Bont de voorstelling De hompelaar, een coproductie van Wederzijds en poppentheatergezelschap Gnaffel. Nogal wat onderwerpen die tot de taboes van het jeugdtheater gerekend kunnen worden, passeren hier de revue: seks, dood, zelfmoord, oorlog. Hoewel De Bont de prijs voor de beste Nederlandse jeugdtheatervoorstelling ontvangt, zijn er ook volwassenen, vooral in de wereld van de politiek en het onderwijs, die zich afvragen of deze voorstelling wel voor kinderen geschikt is. Rondom De hompelaar ontspint zich zodoende een discours over de vraag of jeugdtheater met andere maatstaven moet worden beoordeeld dan theater voor volwassenen (Dieleman 2013, 33-35).

\section{ANNE EN ZEF}

Twee jaar later is Wederzijds gefuseerd met een ander Amsterdams jeugdgezelschap, Huis aan de Amstel. Het fusiegezelschap de Toneelmakerij is sindsdien het grootste jeugdtheatergezelschap van Nederland. Daarvoor schrijft en regisseert De Bont in 2009 opnieuw een stuk over geweld, oorlog en dood: Anne en Zef. In Anne en Zef ontmoet de Albanese jongen Zef Bunga, die slachtoffer is van de bloedwraak

(5) Zowel Mirad als zijn moeder worden in deel twee, het vervolg op Mirad een jongen uit Bosnië, ten tonele gevoerd. Ondanks dat Mirad hier wel als personage verschijnt, heeft ook deze voorstelling dezelfde eenvoudige en verhalende stijl als deel 1 . 


\section{DOSSIER}

Zef Bunga heeft

Anne Frank gekust

(vervolg)

_ Rian Gerritsen en Laura de Boer in Anne en Zef, de Toneelmakerij, 2009.

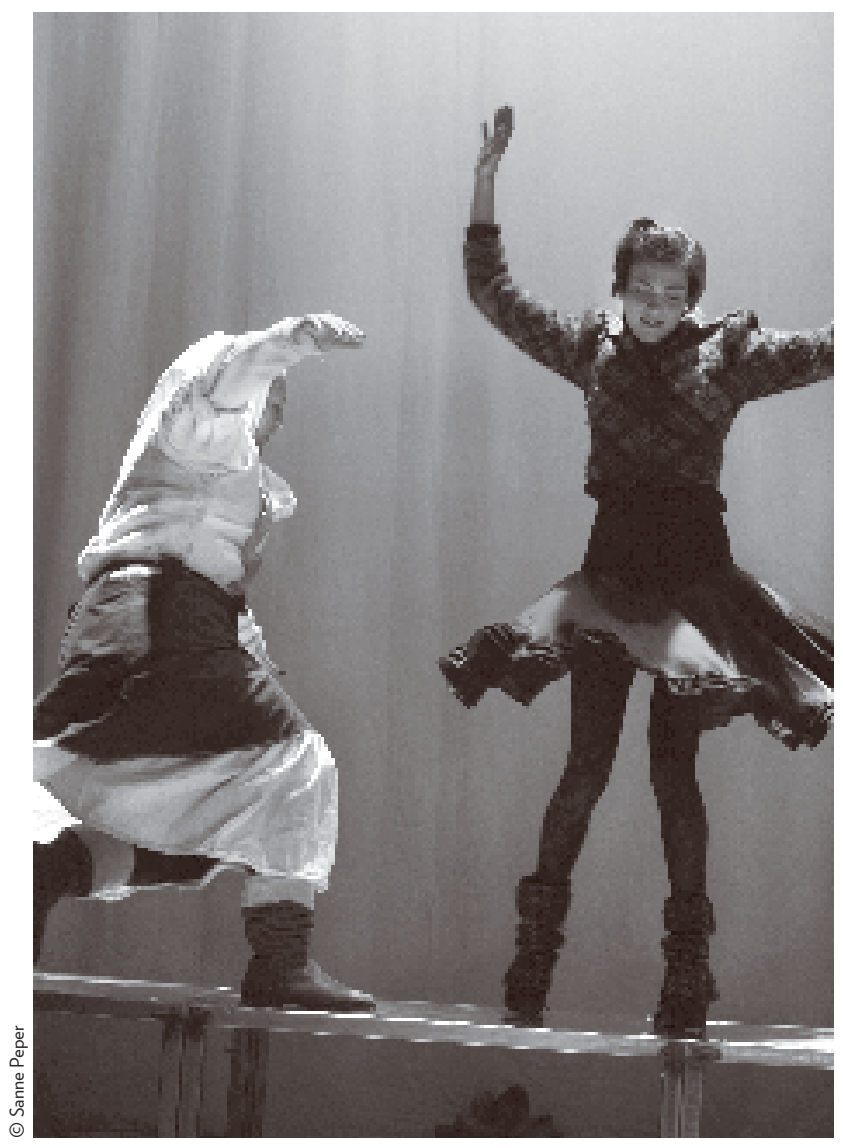

tussen twee Albanese families, na zijn dood Anne Frank, die in het concentratiekamp Bergen-Belsen om het leven is gekomen. De Bont kreeg het idee voor dit stuk na lezing van een krantenartikel waarin beschreven werd hoe duizenden Albanese jongens en mannen thuis gevangen zitten omdat hun familie verwikkeld is in een bloedwraakvete. De wet van de bloedwraak maakt deel uit van de Kanun, een systeem van wetten dat teruggaat tot de vijftiende eeuw. Na de val van het communisme grijpt de bevolking terug op die oude wetten en is ook de bloedwraak weer actueel (Wenzel 2009). Een bron voor de dramatisering is duidelijk Ismail Kadares Broken April wiens protagonist Gjorg in Ad de Bonts toneelstuk als de oom van Zef opdoemt. Anne en Zef is in meerdere opzichten een complexe constructie van performing history. In zijn studie Performing History constateert Freddie Rokem dat de geschiedenis als zodanig alleen begrepen en waargenomen kan worden als ze een discours vormt (Rokem 2000, xi). De gedramatiseerde, gestructureerde herhaling van gebeurtenissen uit het verleden is een vorm van reflectie op en interpretatie van het verleden en in die zin een vorm van geschiedschrijving. Ad de Bont plaatst in het stuk Anne en Zef niet alleen verschillende tijdlagen naast elkaar, maar hij refereert tegelijkertijd aan zowel fictieve als reële personen. De tijd waarin de dramatische gebeurtenissen zich afspelen, is het hiernamaals, de ontmoeting tussen de kinderen vindt na hun dood plaats. Zefs verhaal wordt als actueel gepresenteerd, Anne Franks verhaal speelt zich af in 1944-1945. De gewelddadige dood van beide kinderen maakt de ontmoeting na de dood mogelijk, maar het zijn de twee jaren van onderduiken die hen in het drama met elkaar verbinden.

De enscenering uit 2009 is bijna net zo eenvoudig vormgegeven als zijn beroemde voorganger Mirad een jongen uit Bosnië. Ook in deze voorstelling ligt de nadruk op de tekst. Er zijn slechts vier personages. Naast Anne en Zef zijn dat de vader en moeder van Zef. Het decor bestaat uit een U-vormige, verhoogde loopplank die het speelvlak omgeeft. Rechts achter de loopplank rijst een toren omhoog die zowel een kulla, een typisch Albanees torenhuis, als een van de crematoria van Auschwitz citeert. Daarachter is een groot horizondoek dat in verschillende kleuren kan worden aangelicht. Op dat doek wordt bij aanvang ook de dood van hoofdpersoon Zef in beeld gebracht. We zien in een korte film hoe Zef na twee jaar onderduiken zijn schuilplaats in de Albanese 
bergen verlaat en door een lid van de rivaliserende familie wordt neergeschoten. Daarmee wordt een moord die zijn broer heeft gepleegd gewroken. Op zijn beurt pleegde zijn broer die moord om de dood van een oom te wreken.

Na de filmbeelden wordt de focus naar de eigenlijke speelvloer verplaatst. Zef, vertolkt door dezelfde acteur als in de film, ontdekt dat hij de aarde ontstegen is en wordt in het hiernamaals verwelkomd door Anne Frank. Net als Zef is zij op vijftienjarige leeftijd gestorven en net als Zef is ook zij twee jaar opgesloten geweest. Hoewel Anne Franks onderduikervaring duidelijk het herinneringskader bepaalt, is er geen sprake van concurrerende herinneringen (vgl. Rothberg 2011, 535). De vergelijking van Annes en Zefs onderduikervaring berust zowel op symmetrie als asymmetrie. Hoewel ze de ervaring van twee jaar opgesloten-zijn gemeen hebben, merkt Zef op dat er verschillende redenen voor waren en hij concludeert: 'Voor jou was het nog moeilijker.' Anne wijst Zefs uitleg af, maar Zef insisteert op het verschil tussen de vervolging van Joden door Nationaalsocialisten en de wetten van de Kanun (De Bont 2009, 38). Door te benadrukken dat zij beiden slachtoffer zijn van geweld waar ze zelf part noch deel aan hebben, wordt het unieke karakter van de Holocaust als het ware in een 'multidirectioneel' krachtenveld van traumatiserende herinneringen in kaart gebracht (Rothberg 2011).

Hoewel De Bont in deze voorstelling de uitzichtloosheid van de Albanese familievetes een centrale positie toekent, is er toch sprake van een bedachtzaam doorgronden van verschillende traumatische herinneringsnarratieven. De geschiedenis van Zef krijgt de meeste aandacht. De ontstaansgeschiedenis van de vete wordt nauwkeurig uit de doeken gedaan, net als de verschillende manieren waarop de vader en moeder van Zef zich daartoe verhouden. De moeder vindt dat haar echtgenoot zijn verantwoordelijkheid moet nemen en de moord op zijn broer moet wreken, terwijl de vader de zinloosheid van de bloedwraak inziet, er zich aan wil onttrekken en de keten van geweld doorbreken. De tragiek is dat uiteindelijk zijn oudste zoon de keten van bloedwraak alsnog voortzet en zijn jongste zoon daarvan het volgende slachtoffer wordt.

De historische en iconische figuur Anne Frank en haar dagboekaantekeningen worden hier min of meer bekend verondersteld, als onderdeel van de culturele herinnering. 'Heb je mijn boek niet gelezen?' vraagt Anne in de voorstelling aan Zef, die dat inderdaad bevestigend beantwoordt. Hoewel juist de onderduikervaring beide kinderen verbindt, laat De Bont Anne niet uit haar dagboek citeren maar ensceneert hij haar 'verloren' herinnering. De drie fictieve dagboekfragmenten die Anne in de vorm van drie lange monologen in de voorstelling uitspeelt, vertellen haar ervaringen in Westerbork, Auschwitz-Birkenau en Bergen-Belsen. Ad de Bont beëindigt dus het verhaal van Anne. Als Zef Anne verbaasd vraagt of ze na de deportatie verder heeft geschreven, antwoordt ze: 'Ik kon niet meer zonder. [...] Eerst op steen. [En daarna] in het zand, in de lucht. En op het laatst alleen nog in mijn hoofd.' (De Bont 2009, 15) Annes kostuum, een rood geruit mantelpakje, refereert aan haar befaamde dagboek. In de enscenering van Ad de Bont belichaamt ze als het ware dit dagboek, belichaamt ze het schrijven van haar laatste zeven maanden. ${ }^{6}$
(6) Ad de Bont baseert het 'onbekende dagboek' op de reconstructie van de laatste zeven maanden van Anne Frank (vgl. Lindwer 1988). De beschrijving van Westerbork als voorportaal van de dood' refereert o.a. aan Jacques Pressers Ondergang. De vervolging en verdelging van het Nederlandse jodendom 19401945 (1985). 
Zef Bunga heeft

Anne Frank gekust (vervolg)
In het eerste dagboekfragment wordt de situatie in het doorgangskamp Westerbork beschreven, in het tweede de omstandigheden in het concentratiekamp van Auschwitz-Birkenau. Nadat Zef zijn vriendschap met Edi heeft vertolkt, die op grond van de wetten van de Kanun de rol van vijand werd opgelegd, zingen de acteurs samen het Jiddische volkslied Di Sun ot far mir noch kejnmul nit geschajnt (De zon heeft voor mij nog nooit geschenen). Terwijl Anne met ingetogen emoties en een haast geforceerde glimlach haar verhaal frontaal aan het publiek vertelt, zitten de andere acteurs onder de loopplank en tonen de gebaren van 'niets horen, niets zien, niets zeggen'. In zekere zin representeren ze op deze manier de geschiedenis van de afwezige getuige van de Holocaust. Met Annes 'onbekende dagboek' uit Auschwitz en de contrasterende gebaren van de acteurs, die als spiegelbeeld van het publiek geënsceneerd zijn, wordt niet alleen de time-lag tussen de werkelijke gebeurtenissen en de theatrale re-enactment (Rokem 2000,7) zichtbaar, maar tegelijkertijd de breuk tussen de realiteit van Auschwitz-Birkenau en de theatrale representatie. In de laatste monoloog beschrijft Anne de dood van haar zus Margot, de ontmoeting met haar schoolvriendin Hanneli en haar eigen benarde situatie in de 'bedompte, stinkende barak' in Bergen-Belsen. De Bont suggereert dat dit de laatste dagboekaantekeningen voor haar dood zijn. Zij voelt haar einde naderen:

Een paar dagen na die ontmoeting werden we overgebracht naar deze barak. Net als Margot moest ik gedragen worden want ik had de kracht niet meer om op mijn benen te staan. Maar het is goed. De kring is rond. Ik kan gaan.

De lucht wankelt, de grond tolt. Waar britsen stonden, schieten lichtflitsen omhoog. Wind verandert in water, adem in staal. Een scherpe pijn wordt een streling. (De Bont 2009, 45)

In het moment van sterven vallen de beleveniswereld van Anne en die van Zef samen. Anne herhaalt precies de woorden waarmee Zef aan het begin van het stuk in de wereld van de doden ontwaakt. Het is deze onmogelijke herinnering, de herinnering aan de dood, waarin ze elkaar herkennen.

Hoewel de aandacht in de voorstelling vooral uitgaat naar de gebeurtenissen die tot de dood van Zef hebben geleid, is Anne met haar drie monologen het meest complexe personage in het stuk. De ingetogen manier waarop Laura de Boer die monologen vertolkt staat in contrast met de haast clowneske manier waarop Floris Verkerk als Zef verslag doet van zijn familiegeschiedenis. Het verhaal van Zef en de Albanese bloedwraak wordt veruiterlijkt aan de hand van het conflict tussen de beide ouders, terwijl het personage zelf, zowel door de tekst als door het spel van Verkerk, hoofdzakelijk als een uitgelaten puber wordt neergezet. Niettemin verwijst Ad de Bonts enscenering van Zef als 'stripfiguur' op de momenten dat hij zijn ervaringen vertolkt naar de tekortkomingen die de consequentie zijn van zijn onderduiksituatie. Zijn taal wordt in deze scènes gekenmerkt door een sterk elliptische structuur, hij gebruikt nauwelijks werkwoorden om zijn familie of zijn vriendschap met Edi te beschrijven, hij is dus letterlijk gestript van een actieve houding tot de wereld en 
tot zichzelf. Zef beëindigt zijn clowneske performances steeds met een koppig en definitief 'klaar', waarmee hij uiteindelijk stellig de grenzen van humor en groteske van zijn pijnlijke ervaring duidelijk maakt.

Dat de verschrikkingen van de oorlog, de Holocaust en die van de Albanese familievetes juist in een voorstelling voor kinderen vanaf tien jaar aan bod komen, is gezien de recente geschiedenis van het Nederlandse jeugdtheater niet zo verwonderlijk. Toch weet De Bont de toon van de voorstelling opvallend licht te houden. De ontluikende liefde tussen Anne en Zef en de soms onhandige manier waarop beiden met die gevoelens van verliefdheid omgaan, biedt een mooi tegenwicht tegen de uitzichtloze situatie waarin ze voor hun dood waren beland. In het begin van de voorstelling (na de filmbeelden) reciteren de acteurs in koor: 'Edi van de Markajs heeft Zef Bunga doodgeschoten.' Aan het eind van de voorstelling herhalen ze op dezelfde manier: 'Zef Bunga heeft Anne Frank gekust.'

\section{CONCLUSIE}

In de geschiedenis van de representatie van (het dagboek van) Anne Frank op toneel zijn twee visies onderscheiden die het discours in belangrijke mate bepaald hebben. De eerste focust op Anne Frank als universeel symbool van humanisme. De tweede benadrukt de Joodse afkomst van Anne Frank en de uiteindelijke vernietiging van Joden tijdens de Holocaust. De groots gemonteerde en commercieel geëxploiteerde productie Anne uit 2014 plaatst zich nadrukkelijk in dat laatste discours door een Joods schrijversechtpaar de bewerking te laten maken en het concentratiekamp als basis voor een raamvertelling te nemen, waarin het dagboek zelf als het ware is ingekapseld. De jeugdvoorstelling Anne en Zef(2009) onttrekt zich er juist aan. De gebeurtenissen in het dagboek zelf worden als bekend verondersteld, waardoor enerzijds de iconische status van Anne Frank gethematiseerd kan worden en anderzijds de aandacht op haar verblijf in Westerbork en Auschwitz-Birkenau en haar dood in Bergen-Belsen komt te liggen. De Holocaust wordt samen met andere vormen van oorlog en geweld in kaart gebracht, zodat de nadruk komt te liggen op de wijze waarop kinderen er onder te lijden hebben. De voorstelling kan als een aanklacht worden gezien tegen de manier waarop kinderen tot slachtoffers van geweld gemaakt worden; of dat nu de historische slachtoffers van het nazigeweld betreft of die van oorlogsgeweld in actuele conflictgebieden elders in de wereld.

\section{BIBLIOGRAFIE}

- Anne en Zef, dvd-registratie van de voorstelling, Amsterdam, de Toneelmakerij, 2009.

- 'Anne synopsis'. www.theateramsterdam.nl/nl/Anne-de-theatervoorstelling/synopsis.html (geraadpleegd 6 mei 2015).

- M. S. Arnoni, Moeder was niet thuis voor haar begrafenis. Verslag van een reis door een verloren vaderland. Een overlevende van Auschwitz-Birkenau terug in Polen, Amsterdam: De Bezige Bij, 1982. 
Zef Bunga heeft Anne Frank gekust (vervolg)
- Michael Bachmann, Der abwesende Zeuge. Autorisierungsstrategien in Darstellungen der Shoah, Tübingen: Francke, 2010.

- David Barnouw, Het fenomeen Anne Frank, Amsterdam: Bert Bakker, 2012.

- Simon van den Berg, 'Zo groot dat benauwdheid Achterhuis verloren gaat', Het Parool, 9 mei 2014.

- Bruno Bettelheim, 'The Ignored Lesson of Anne Frank', Harper's Magazine, november 1960, 45-50.

- -, Het nut van sprookjes [1976], Amsterdam: De Bezige Bij, 1980.

- Ad de Bont, Anne en Zef, script van de voorstelling, Amsterdam: de Toneelmakerij, 2009. Première 24 januari 2009.

- -, Mirad een jongen uit Bosnië, De Nieuwe Toneelbibliotheek, 1993, www.denieuwetoneelbibliotheek.nl/files/ get/2815 (geraadpleegd 22 januari 2015).

- Marvin Carlson, The haunted stage. The theatre as memory machine, University of Michigan Press, 2001.

- Terrence Des Pres, 'Holocaust Laughter?', in Berel Lang (red.), Writing and the Holocaust. New York \& London: Holmbs \& Meier, 1988, 216-233.

- Cock Dieleman, 'De moeizame samenwerking tussen jeugdtheater en basisonderwijs in Nederland', Cultuur + Educatie 13 (36), 2013, 26-40.

- Frances Goodrich \& Albert Hackett, The Diary of Anne Frank. A Play in Two Acts, Toronto: Irwin, 1964.

- Lawrence Langer, 'Americanization of the Holocaust on Stage and Screen', in Id. (red.), Admitting the Holocaust. Collected Essays, Oxford University Press, 1996, 157-178.

- Meyer Levin, 'The Child Behind the Secret Door', The New York Times Book Review, 15 juni 1952.

- Willy Lindwer, De laatste zeven maanden. Vrouwen in het spoor van Anne Frank, Hilversum: Gooi \& Sticht, 1988.

- Hans van Maanen, Het Nederlandse toneelbestel van 1945 tot 1995, Amsterdam: Amsterdam University Press, 1997.

- Dennis Meyer, 'Teneeter speelt Ifigeneia koningskind: Opbloei van het jeugdtheater', in R. L. Erenstein (red.), Een theatergeschiedenis der Nederlanden. tien eeuwen drama en theater in Nederland en Vlaanderen, Amsterdam: Amsterdam University Press, 1996, 832-839.

- Cynthia Ozick, 'Who Owns Anne Frank?' [1997], in Id., Quarrel \& Quandary. Essays by Cynthia Ozick, New York: Knopf, 2000, 74-102.

- Jacques Presser, Ondergang. De vervolging en verdelging van het Nederlandse jodendom 1940-1945, 2 vol., Den Haag: Staatsuitgeverij, 1985.

- Freddie Rokem, Performing History. Theatrical representations of the past in contemporary theatre, lowa City: University of lowa Press, 2000.

- Jan Romein, 'Kinderstem', Het Parool, 3 april 1946 (titelpagina).

- Alvin H. Rosenfeld, A Double Dying. Reflections on Holocaust Literature, Bloomington \& London: Indiana University Press, 1980.

- Michael Rothberg, 'From Gaza to Warsaw: Mapping Multidirectional Memory', Criticism 53 (4), 2011, 523-548.

- Manon van de Water, Theatre, youth and culture. A critical and historical exploration, New York: Palgrave Macmillan, 2012

- Herien Wensink, 'Deze Anne mist gelaagdheid', NRC Handelsblad, 9 mei 2014 (titelpagina).

- Annemarie Wenzel, 'Interview met Ad de Bont over Anne en Zef', Amsterdam, De Toneelmakerij, 2009 (op website niet meer toegankelijk).

- James E. Young, Writing and Rewriting the Holocaust. Narrative and the Consequences of Interpretation, Bloomington: Indiana University Press, 1988. 